PR

46,7

1214

\section{INTRODUCTION Guest editorial}

A special issue: human resources and workplace innovations: practices, perspectives and paradigms - a tribute and dedication to Professor Tom Redman

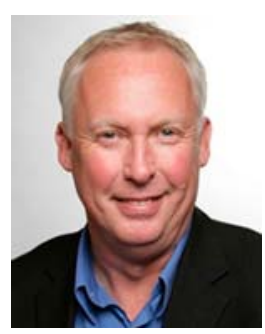

Tom Redman

This special issue is dedicated to the late Professor Tom Redman (63), who died unexpectedly on 18 December 2015. He was the Editor of Personnel Review during 1995-2006, when he led significant improvements to the journal's quality and reputation. Tom's work was innovative in many ways. We think that he would have appreciated this special issue of Personnel Review and are very sorry that he is no longer with us in person to discuss it.

Tom was a Professor of Human Resource Management (HRM) at the Durham University; he spent the early part of his academic career at the Teesside University. He was a very kind and warm person who will be greatly missed. He was well known in the UK and internationally not only as an outstanding scholar, but also as a good and modest man. Although based in the UK for his whole academic career, Tom's work was international in scope and he was a frequent visitor to other European countries, as well as to Asia, Australia, New Zealand and North America. He spent periods as a visitor, for example, in Hong Kong and Australian universities, where he was well liked and respected, not least for the time he generously devoted to helping students and junior colleagues.

His research, teaching and service was informed by his earlier experience as a practitioner. Tom had spent a decade working in industry in quality, production and HRM positions (mainly with Royal Worcester Porcelain) before he re-entered academic life. His research interests included industrial relations, union commitment and participation, employee commitment, age discrimination, and HRM. Most recently he was working on several projects on employee attitudes and service quality. That Tom's passing was premature is illustrated by the fact that he left a significant body of work in progress and an active research programme. At least some of this work will still be published with co-authors, but the published work will be poorer for Tom's absence.

Tom's research was published in many leading journals including Journal of Applied Psychology, Journal of Vocational Behavior, British Journal of Management, Journal of

(c) Greg J. Bamber, Timothy Bartram and Pauline Stanton. Published by Emerald Publishing Limited. This article is published under the Creative Commons Attribution (CC BY 4.0) licence. Anyone may reproduce, distribute, translate and create derivative works of this article (for both commercial and non-commercial purposes), subject to full attribution to the original publication and authors. The full terms of this licence may be seen at http://creativecommons.org/licences/by/4.0/legalcode 
Management Studies, Industrial Relations, Journal of Labor Research, Journal of Cross Cultural Psychology, Human Relations, International Journal of Human Resource Management, Human Resource Management Journal, Work, Employment \& Society, as well as Personnel Review. In addition, he co-authored and edited books with several others including: Nick Bacon, Greg Bamber, Tony Dundon, Ed Snape, Scott Snell and Adrian Wilkinson. These include his co-edited and widely used HRM text. In addition to his sterling work with Personnel Review, he served on the editorial board of several academic journals including the Journal of Management Studies and Leadership and Organizational Development Journal. He was a Fellow of the Chartered Institute of Personnel and Development.

Tom was a Lancashire man who had lived for many years in Yorkshire. He was a very successful academic and a lovely person. He died suddenly in Thailand, while on the way back to the UK from a research visit to China. He was there with Edwina, his wife. He is survived by Edwina and his two daughters, Rosie and Rachel. We offer our sincere condolences and sympathy to Tom's family and many friends.

Greg J. Bamber

Department of Management, Australian Consortium for Research in Employment and Work, Centre for Global Business, Monash University, Melbourne, Australia and Newcastle University, Newcastle upon Tyne, UK

Timothy Bartram Department of Management and Marketing, La Trobe Business School, College of Arts, Social Sciences and Commerce, La Trobe University, Melbourne, Australia, and

Pauline Stanton School of Management, College of Business, Royal Melbourne Institute of Technology (RMIT) University, Melbourne, Australia

\section{Acknowledgements}

There are tributes to Tom Redman by many others in Greg Bamber and Ed Snape (2016) "The late Professor Tom Redman, Editor of Personnel Review 1995-2006", Personnel Review, 45(3): pp. 1-4: www.emeraldinsight.com/doi/abs/10.1108/PR-02-2016-0027. Also see: Ed Snape and Greg Bamber (2016) "Professor Tom Redman: Obituary", Human Resource Management Journal, 26 (2): pp. 232-234. The editors thank all of the authors of the articles and the many referees who advised on which articles to accept in this special issue and then on how to improve successive versions of them. The editors also appreciate the most helpful cooperation of Nelarine Cornelius, Editor, and of the publishers of Personnel Review. Photo source: Durham University. The authors thank the Australian Research Council for financial support (Project No. LP110200528). 